\section{How it all began: from conception to birth to early adulthood}

\author{
Alex Williamson, ${ }^{1}$ Mike Hayes, ${ }^{2}$ Barry Pless ${ }^{3}$
}

In honour of this 20th anniversary volume, Brian Johnston asked me-as the founding editor-to write something about the origins of the journal. I agreed, providing Mike Hayes and Alex Williamson would coauthor. As you will learn from the discussion below, both played a pivotal role in the journal's creation and with that came the birth of our enduring friendships. I know they both share my pride in what may well prove to be our most important professional accomplishment. First, it is important to know how each of them came to this stage, and introductions are in order because none of us are 'household names,' if ever we were.

Alex Williamson is now happily retired, but in the early $90 \mathrm{~s}$ she was the Publishing Director at the BMJ Publishing Group. Her duties included managing more than 20 medical specialty journals and commissioning new titles as the need arose. Fortunately for us, among several others she brought to the Publishing Group, she recognised the need for a journal addressing injuries. Alex read zoology and biochemistry at the University and, after a brief spell in R\&D for a pharmaceutical company, started working her way up through various prestigious UK publishing houses. She now devotes her time to enjoying herself, occasionally caring for her two grandchildren, being Treasurer for Charcot-Marie-Tooth UK-a small medical charity-and serving on various lay medical research panels.

Before his recent retirement, Mike Hayes spent 30 years as the head of research and development for the Child Accident Prevention Trust (CAPT) in the UK. The Trust was founded, in part, by the late Hugh Jackson, one of the first Honorary Editors of Injury Prevention. At the time, Mike's main responsibilities included oversight of all the technical aspects of CAPT's work and ensuring that what it said and did was up-to-date and scientifically sound. Mike has a degree in physics from the University of Birmingham and did his $\mathrm{PhD}$ at that university's

${ }^{1}$ Fetcham, UK; ${ }^{2}$ Birmingham, UK; ${ }^{3}$ Westmount, Quebec, Canada

Correspondence to Dr Barry Pless, 434 Lansdowne, Westmount, Quebec, Canada H3Y2V2; barry.pless@mcgill.ca accident research unit. He now works on a freelance basis as the Trust's principal consultant and continues to be active in European and UK product safety standardisation.

Both did far more than is described in the commentary. Mike kept a steady hand on the helm throughout all the difficult early years. Without his and Alex's unflagging support I am certain that the journal would have folded long ago. It is not an easy matter to introduce a new journal, especially in a field that at the time (and perhaps still) was sruggling for identity. It is possibly even more challenging to keep a new journal alive during financially lean years. But, Alex made certain we had support from all the right people, especially Richard Smith, the BMJ editor and our boss. So, here we are, 20 years down the road and thriving. All credit to Mike, Alex and, of course, to Brian.

The rest of this account will unfold as a conversational narrative.

Barry Pless: For me, the journal story began some time in 1990-1991 when I was on sabbatical leave and attached to the CAPT. Mike Hayes was, in effect, my leader and we became close friends. Before that sabbatical, I had been heavily involved in injury prevention research in childhood while at the University of Rochester and then at McGill University in Montreal. I was then a tenured full professor and a National Health Scientist, and that permitted me to devote so much time to my research. I served as editor-in-chief from 1995 to 2007 and I am now Professor Emeritus of Pediatrics and Epidemiology at McGill, more or less happily retired, but still doing what I can to help the journal by writing Global News Highlights, fillers and contributing to our blog.

Mike Hayes: It was a stimulating and instructive year, with Barry questioning everything the Trust did, forcing us to justify our actions (and inactions) and pointing CAPT towards the evidence. To put it simply, Barry helped to put our work on a stronger scientific basis and he became my mentor and friend.

Barry Pless: Mike's expertise was broad and included, alongside product safety regulations in Europe (his specialty), all things technical, specially computers.
(Whenever we faced a problem with these newfangled gadgets, he would urge we consult 'the book of words'. Surprisingly, that usually solved it!) More importantly, he had a special talent for understanding how to move things forward in our field, which at the time was struggling for identity and acceptance.

Mike Hayes: In 1992, during a visit with Prof Jo Sibert in Cardiff, I accompanied him to a meeting with Mary Banks, the book commissioning editor of BMJ. She was seeking his opinion on what books were needed in paediatrics. I was surprised when Mary turned to me and asked what I thought. (You need to understand that I was then working for a small but, on a good day, influential UK charity, the CAPT.) I was surprised because I was not used to being asked such a question by a major medical publishing house. However, one idea that had been on my mind for some time was the need for a channel of communication between the small but expanding community of academics and specialist injury prevention organisations. To my added surprise, the next day I received a phone call inviting me to meet Alex Williamson to further consider the question. This turned out to be the first of several meetings and the start of a precious friendship.

Alex Williamson: As the specialty journals publisher at the $B M J$, I was always hunting for new journal ideas and this one seemed a likely candidate. When I met with Mike Hayes, he was very supportive and inspired me with his enthusiasm. He later told me that Barry Pless was interested in editing it!

Barry Pless: I was extremely keen to become involved. As matters proceeded, I made it clear that I wanted to be considered as a candidate for editor. Apparently, Mike agreed and arranged for me to meet Alex and Richard Smith. One thing led to another and eventually it was decided that I would serve as the first editor of Injury Prevention.

Mike Hayes: Alex had asked me who I thought should be the editor. Barry Pless's name came instantly to mind-he was respected by his peers, had an extensive list of publications and was known to the BMJ's editor, Richard Smith.

Alex Williamson: I still had to ascertain whether there was enough good research around to sustain a quality publication and if there was a market for it. I had many meetings with interested parties to determine the viability of such a publication. I also canvassed several key people in the field: Jo Sibert, Hugh Jackson and Fred Rivara, among others. All were supportive and encouraged me to proceed. 
Mike Hayes: The first World Conference on Injury Prevention had taken place in Stockholm in 1989. It demonstrated that there was a growing community of researchers and others committed to the field and that some solid research was being done. Stockholm proved to be the first conference in a series; the second was in Atlanta, GA, in 1993, and Alex Williamson agreed to attend.

Alex Williamson: This was an exciting visit. This was when ISCAIP was born and it was clearly interested in being associated with our putative journal. The visit to Atlanta also gave me the opportunity to meet Barry Pless. I confess to being somewhat in awe of this famous personage but was soon put at ease. Needless to say, we got on famously and have been friends ever since.

Alex Williamson: Back in London at the BMJ's headquarters, I met with my boss, Richard Smith, then editor of the BMJ and CEO of the Publishing Group. The journal Injury Prevention proposal met with his approval and it is fair to say that he became even more enthusiastic when I told him that Barry Pless wanted to edit it. The journal then got the approval of the powers that be in the publishing group. That's when the hard work really started.

Barry Pless: The year that followed was a mixture of nightmares, excitement and a huge amount of work. We needed to assemble an editorial board and I was determined to recruit every 'big name' I could think of. I also resolved that the Board would have good international representation. Miraculously, I don't recall a single person we invited who declined! This warm acceptance persisted through the many changes in board membership that followed. Initially, we prepared lists of potential subscribers (wildly off target as it turned out) and made all sorts of equally optimistic financial projections. Alex and Mike were essential players as all this rolled out and continued to be so for many years afterwards.

Alex Williamson: The financial modelling indicated that a quarterly journal might be financially viable, though it would never be very profitable. This, however, was one of the bonuses of the BMJ Publishing Group, because while needing to be financially secure, profit was not its primary motive. If a venture was intellectually sound, potentially influential and not likely to sustain huge losses, it could and probably would be supported.

Barry Pless: The first issue appeared in early 1995. The birth issue included an editorial in which I described the first of several personal injuries (this one involving being hit by a car in London when I looked the wrong way) and giving thanks to many people-notably Sue Heels, our first copy editor, and Ann Arnold, our assistant editor. I also gave credit to all the contributors willing to write for a 'spanking new, promising, but untested journal'. Of interest, the authors' list for that issue included, among others, Fred Rivara, (the late) Hugh Jackson, Eleni Petridou, Polly Bijur, Ian Roberts, Robyn Norton, Cheryl Alexander, Terry Nolan, Samuel Forjuoh, Rosa Gofin and Elizabeth Towner. Most of these are now familiar names in the world of injury prevention.

Over the next 13 years of my tenure as editor there were a few triumphs (our first impact factor) and several panic-generating episodes. At one point it seemed we would be shut down but were rescued by Alex, Richard and supporters at the National Institute for Occupational Safety and Health and the Centers for Disease Control (CDC). Along the way, it was decided we would move from four to six issues a year (forcing me to write more editorials-always a mixed blessing because I enjoyed the writing and the pulpit, but hated the deadlines). Equally important was the decision to move from our initial exclusive focus on children and adolescents to include injuries in all age groups and later the gradual, inevitable (and, for me, regrettable) move to electronic publishing - a blessing for readers but possibly a curse for the financial bottom line.

\section{ADDENDUM: THE FUTURE?}

Barry Pless: Brian Johnston asked us to speculate on the role of this journal in the development of an academic specialty. Although some academics, mostly in public health, already specialise in injury prevention, I am convinced that if there is to be any hope of a genuine academic specialty, we must first solidify the place of injury prevention within the broader medical and public health world. I fear we still have a long way to go to achieve that goal, but even if we are farther along than I realise, I am not sure how critical it is to become an academic specialty in order to achieve our real goal-a targetzero for all preventable injuries.

Mike Hayes: I believe one long-standing stumbling block in the path to that goal is that the problem has not yet extended beyond the classic conception of 'public health'. To be effective, public health must include engineering and social issues, such as housing policy, childcare and parenting practices. Accordingly, the journal must strive to be increasingly relevant beyond those trained in public health and medicine. Maybe this could be accomplished in collaboration with other journals so that injury prevention was included in, for example, engineering and housing journals. Nevertheless, public health does or should provide ultimate leadership in the field.

Barry Pless: That said, this journal has earned its place as a major contributor to the legitimacy of the field. As do most journals (most, but by no means all), it adds to the fundamental knowledge base on which any academic discipline is built and, in our case, the foundation on which practical programmes rest. Somehow, critical as that may be, the journal and the discipline alone will not ensure that Injury Prevention achieves the place we believe it deserves, either in academia or in the real world. A social revolution is needed to persuade the public to view injuries as they have come to see smoking and alcohol. Until then, however, Injury Prevention will continue to play a vital role in the sustenance of that movement.

Alex Williamson: Happy birthday!

Competing interests None.

Provenance and peer review Commissioned: internally peer reviewed.

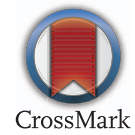

To cite Williamson A, Hayes M, Pless B. Inj Prev 2015;21:2-3.

Received 29 November 2014

Accepted 6 December 2014

Inj Prev 2015;21:2-3.

doi:10.1136/injuryprev-2014-041494 